\title{
Dark Tourism in the EU: Are We Aware of Taking Part in It?
}

\author{
Nikolina Juranović \& Iva Slivar \\ University of Juraj Dobrile, Pula, CROATIA \\ Faculty of Economics and Tourism "Dr. M. Mirkovič" \\ Sanja Kovačić \\ University of Novi Sad, SERBIA \\ Department of Geography, Tourism and Hospitality
}

Received: 18 December 2020 - Accepted: 17 April 2021 - Published Online: 3 July 2021

\begin{abstract}
Dark tourism attractions and sites are gaining increasing attention, whereas dark tourism is considered one of the relatively recent and growing trends in the turbulent tourism market. Along with providing a theoretical framework, this paper aims to explore the tourism market of dark tourism and the motives of tourist demand. The perspectives of the population of the Republic of Croatia on dark tourism as a concept as well as the offer side of dark tourism are presented. These findings will be useful in designing and improving this kind of tourist offer, which also represents the main purpose of this paper. The research instrument was an original questionnaire. The main hypothesis of research refers to insufficient tourists' awareness of their participation in dark tourism, which was confirmed by the carried research. The new frontier of research refers to their propensity of visit in case they would be aware of the tragic history related to a site; namely if they knew a site they visited previously is classified as a dark tourism site - would they still have chosen to visit it?
\end{abstract}

Keywords: dark tourism, Europe, Croatia, awareness of participation.

\section{Introduction}

Dark tourism is a specific form of tourism that involves travel to places where tragic, morbid or gruesome events have occurred as well as to places that have just been brought in connection with them (Foley \& John, 1996).

Vukonić (2010) states that "tragic events in the history of mankind attract today's generations of tourists in all parts of the world, with almost the same intensity as the bright events and successes of mankind." The increase in revenues and higher living standards have influenced an increase in travel intensity, so traveling has become an integral part of life. The requirements of tourist demand are increasing and tourists no longer need a traditional holiday but require a new tourist product.

(C) Authors. Terms and conditions of Creative Commons Attribution 4.0 International (CC BY 4.0) apply. Correspondence: Iva Slivar, University of Juraj Dobrile, Faculty of Economics and Tourism "Dr. M. Mirković”, Pula, CROATIA. E-mail: iva.slivar@unipu.hr. 
The concept of dark tourism has gained considerable popularity at the very end of the 20th century. Today, there are numerous locations marked by disasters, suffering and human death, which are, at the same time, of interest to modern tourists. The increase in demand for dark tourism can also be attributed to the advancement of information technology through which all news and information from the world are constantly available. Facebook and Twitter are just some of the social networks through which tourists get information and which draws people's attention to places of disaster and conflict (The Conversation, 2016).

The main aim of this research is to examine the familiarity of the local population in the Republic of Croatia with the very concept of dark tourism and attitudes towards it. The aim is to investigate the previous involvement of the local population in the travel of this type and as well as to get information about destinations that have been visited. One of the study aims is also to explore the possible motives for such trips. Moreover, the study intends to explore the familiarity of residents with the tourist offer of dark tourism in the European Union. The study will help in determining whether there is a desire among respondents to participate in dark tourism and what is their perception of the possible growth/decline of interest in tourist demand for this tourism form. This research intends also to contribute to a better understanding of the existing but also potential tourist demand in dark tourism.

The paper consists of five chapters, including an introduction and a conclusion. In the second chapter, upon a key summary, the literature review will focus on dark tourism within the EU. The third part refers to the research methodology where the main instrument was the original survey questionnaire, while the results of the same are presented in the fourth chapter. The last chapter deals with concluding remarks.

\section{Literature review: Dark tourism in the EU}

New ideas and opportunities are quickly being adopted by the tourism industry. However, connecting tourism and the dark side of humanity at first glance seems like an incompatible pair and the question was whether there is a way to connect them at all (Hooper \& Lennon, 2017).

Seaton and Lennon (2004, in Sharpley \& Stone, 2009) state that dark tourism has existed since the very beginnings of tourism and that the demand for dark tourism has grown in parallel with the expansion of the tourism industry in the middle of the last century.

Stone (2005) considered traveling associated with death and suffering to be an old concept in the new world and states that some of the earlier journeys associated with dark events were to witness gladiatorial games.

Seaton (2009, in Stone, 2010) believes that Christianity, antiquarianism, and romanticism are three key historical periods of dark tourism. People used to take part in religious pilgrimages to feel the presence of God, think about the meaning of life and death, and escape from everyday life. Under the influence of increasing secularization, there was a reversal in the motivation of tourists to visit cemeteries, churches and holy places. Hedonism, fascination with death, and education have become strong motivators, and religion and spirituality did not remain the primary reasons for visiting certain attractions as reported by MMNieuws.nl (2016).

The term dark tourism is introduced into the academic literature as a consequence of the emergence of an increasing number of dark attractions, which laid the foundation for further research of this term (Stone, 2005). Numerous theorists have recognized the growing interest of tourist demand for dark travel, so, consequently, they have begun to research the phenomenon to understand the same Lennon and Foley (2007). 
2016):

The typology of dark tourism encompasses several dark tourism forms (Fonseca et al.,

- War tourism - which involves travel to war zones for sightseeing and education, seeking evidence of conflict (e.g., Waterloo, 1815);

- Disaster tourism - which includes travel to places marked by a natural disaster or a disaster caused by human error. (e.g., Pompeii);

- Prison tourism - visits to former prisons accompanied by a dark and / or important history (e.g., Alcatraz);

- Cemeteries - visiting cemeteries or individual graves (e.g., Pere Lachaise);

- Ghosts - travel to locations associated with the paranormal (e.g., the Tower of London).

There are many dark attractions and the typology of dark tourism according to the tourism supplier, can be divided into seven dark suppliers, as follows: Dark Fun Factories, Dark Exhibitions, Dark Dungeons, Dark Resting Places, Dark Shrines, Dark Conflict Sites and Dark Camps of Genocide (Stone, 2010).

Kesar and Tomas (2014) claim in their paper that "apart from gaining income and employment of the local population, the commodification of historically sensitive facts related to tragic events ensures a kind of attractiveness of these localities and continuity of the number of visitors."

There are five categories of dark travel activities of this type, and these are (Seaton, 1996, in Stone, 2010):

- travel to witness public executions,

- trips to visit the sites of individual or mass deaths,

- trips to memorial sites, cemeteries, crypts, etc.,

- travel to relive some events or simulate death,

- visiting places that are not the original places where some dark events take

place, but which are brought in connection with the same as war museums, etc.

Vukonić (2010) finds it fascinating that "one of probably the most intriguing issues in tourism is that the motivation for tourist travel turned: from positive to negative." The motives for participating in dark tourism are numerous and some are experiencing a spiritual or retrospective experience, checking and confirming the truth of some events, satisfying the need for authenticity, self-discovery, and learning, the desire to visit places where some important events took place, curiosity, meeting with victims, etc. (Dunkley, 2006, in Robinson, 2015). Experiences that dark tourists can feel are, for example, insecurity, humility, gratitude, and superiority (Tarlow, 2005 and Stone, 2005).

Moreover, literary and film works are increasingly contributing to the importance of dark attractions. Thus, the locations where e.g. The films The Witch of Blair and The Exorcist have become important tourist attractions (Reeves, 2001, Carl et al., 2007, in Strielkowski, 2013)

Europe has not only been a significant tourist region through the historical development of tourism but nowadays, it remained a leading tourist region (UNWTO, 2019). War destruction, natural disasters and various legends create excellent conditions for the development of this form of tourism in many locations of the European Union, and at the same time, such locations marked by suffering, death and terror are causing an increasing interest in tourists to 
demand. Among the most popular attractions of dark tourism are certainly: Waterloo in Belgium, Pompeii in Italy, Paris Catacombs in Paris, Auschwitz concentration camp in Poland, Anne Frank House in the Netherlands, Colosseum in Italy, etc.

The tourist offers also recognized that the interest in this tourism form is growing. Although larger tour operators do not have offers tailored to meet the requirements of this specific group of tourists, local tourism providers have found ways to make a profit. Costa Concordia in Italy can be taken as an example. The news of the catastrophe with many fatalities went around the world in a few moments. Giglio Island, a place unknown to most people, suddenly found its way into all the media. Not long after, the first interested people began to come to the small island to see the largest passenger ship ever sunk. The Telegraph (2014) states that tourists were offered boat tours lasting an hour for the price of 10 euros in which tour organizers guaranteed tourists to observe and tour the shipwreck from close range. The Daily Mail Online (2012) states that the mayor of Giglia, Sergio Ortelli, confirmed a noticeable increase in the number of visitors which contributed that the island itself has become a kind of museum. But interest in the Costa Concordia did not diminish even after dragging her to Genoa where she was supposed to be destroyed. The Daily Mail Online (2014) states that local businesses in Genoa recognized the potential for further earnings and then also began to offer boat tours of the wreck, and many accommodation facilities and restaurants in their offer also emphasized the "view of the Costa Concordia" to attract more tourists.

\section{Methodology and data}

The instrument for researching the attitudes and perceptions of the Croatian population was a questionnaire, both pen and paper and online survey. The survey consisted of 13 questions, three of which were related to the socio-demographic characteristics of the respondents, four questions were formed in such a way as to allow multiple-choice, four questions were closed, i.e.

The study sample is convenient, combined with a snowball sample technique, as respondents were asked to share the survey with their friends and acquaintances. All adults with their residence within the Republic of Croatia were targeted with the survey.

The survey was conducted during March and April 2017, and a total of 234 respondents completed the survey of which 9 or $3.8 \%$, respectively, were excluded because of the incomplete surveys. The results were obtained based on the total of 225 questionnaires.

There was a higher number of female respondents in the survey: 139 or $61.78 \%$ were female and 84 or $37.33 \%$ were male. Two respondents did not state gender, and they represent $0.89 \%$ of the sample.

The respondents were divided into four groups. The first group refers to respondents aged 18 - 34 years, the second group includes respondents aged $35-49$, the third group represents persons aged $50-65$ years, and the last group refers to respondents aged $65^{+}$. Respondents who did not state their age were grouped separately.

The sociodemographic characteristics of the respondents are shown in Table 1. 
Table 1. Sociodemographic characteristics of respondents (Juranović, 2017)

\begin{tabular}{|c|c|c|c|}
\hline Gender & $\%$ & Education & $\%$ \\
\hline $\begin{array}{l}\text { Male } \\
\text { Female } \\
\text { Missing } \\
\text { data } \\
\end{array}$ & $\begin{array}{l}37.33 \\
61.8 \\
0.89\end{array}$ & \multirow[t]{3}{*}{$\begin{array}{l}\text { Elementary school } \\
\text { Secondary school } \\
\text { High school } \\
\text { Faculty/master/PhD }\end{array}$} & \multirow[t]{3}{*}{$\begin{array}{l}0 \\
52 \\
11.56 \\
36\end{array}$} \\
\hline Age & $\%$ & & \\
\hline $\begin{array}{l}18-34 \\
35-49 \\
50-65 \\
65+ \\
\text { Missing } \\
\text { data }\end{array}$ & $\begin{array}{l}47 \cdot 56 \\
27.11 \\
19.56 \\
5 \cdot 33 \\
0.44\end{array}$ & & \\
\hline
\end{tabular}

Out of a total of 225 respondents, the highest number of respondents - 107 or $47.54 \%$ - is the group of respondents aged 18-34. The smallest number of respondents is in the age group of $65+$ years $(5 \cdot 33 \%)$.

Over half of respondents have finished secondary education (52\%). The higher school has been completed by $11.56 \%$ of respondents, while the number of respondents with faculty/master/Ph.D. was $36 \%$. There are no respondents without qualifications and with primary school.

\section{Results}

\subsection{The familiarity of respondents with dark tourism}

When asked about the definition of dark tourism, respondents were offered a multiple choice of answers and the respondents had to circle those answers that they consider to best fit with the description of dark tourism.

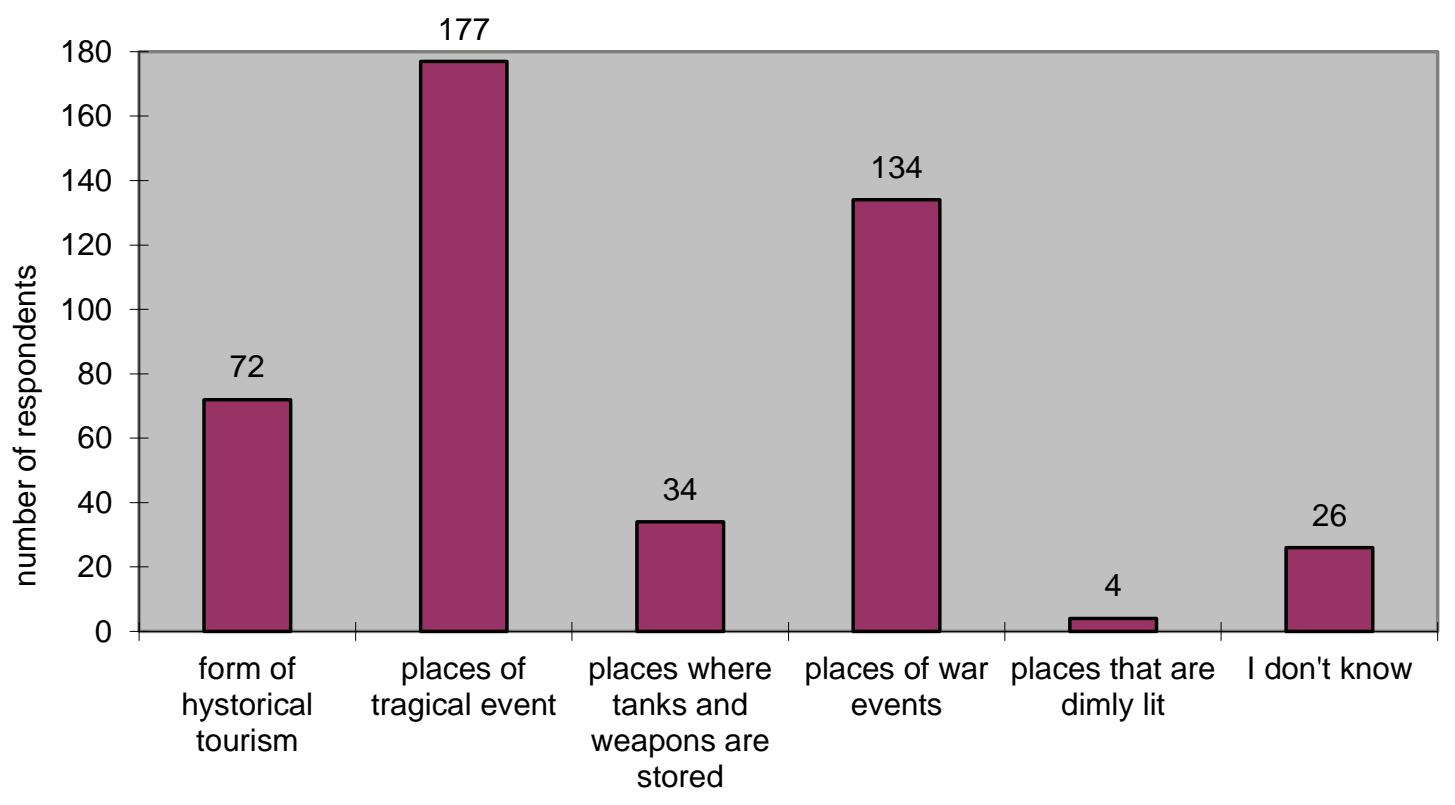

Graph 1. Definition of dark tourism (Juranović, 2017) 
According to Graph 1, the largest number of respondents (78.67\%) would define dark tourism as a place of tragic events. Afterwards, the majority of them connect dark tourism with places of war events (59.56\%) and historical tourism (32\%). The smallest number of respondents believe that dark tourism is a place where tanks and weapons are stored and places that are poorly lit.

In terms of respondents' familiarity with the tourist offer of dark tourism in the European Union (Graph 2), respondents were asked to choose popular dark attractions in the EU they are familiar with. Given a large number of the Member States and the impossibility of offering attractions for each country, to maintain the simplicity of the survey, ten Member States with ten popular dark attractions were selected.

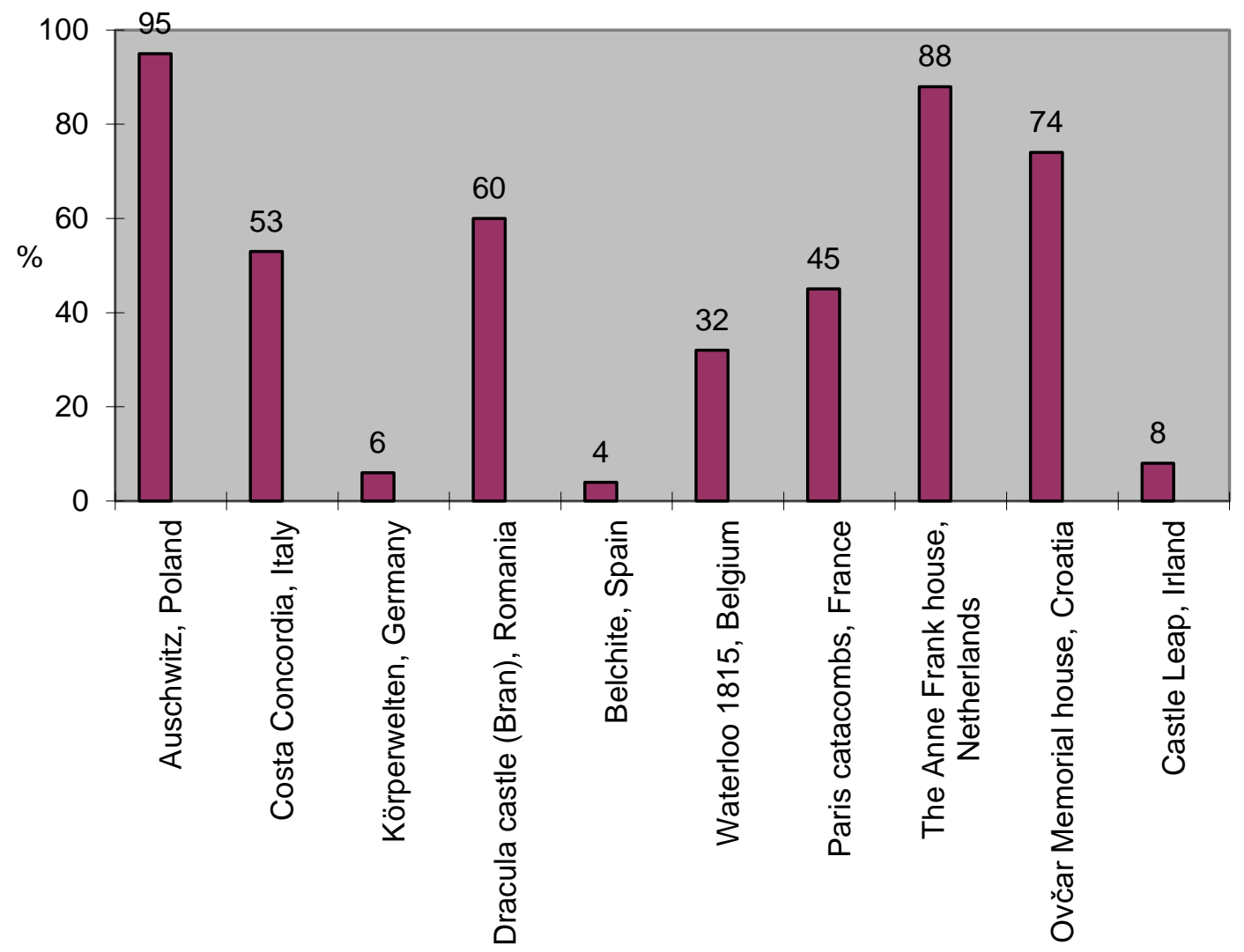

Graph 2. The familiarity of respondents with selected dark attractions in the EU (Juranović, 2017)

Respondents are most familiar with Auschwitz in Poland (94.67\% of respondents). The next three attractions the respondents are most familiar with are the Anne Frank House (Netherlands), the Ovčara Memorial House (Croatia) (74.22\%) and the Bran Castle (Romania) (60.45\%). Almost half of the respondents had heard of Costa Concordia (Italy), while $44.89 \%$ of them have heard for Paris Catacombs (France). Körperwelten Exhibition (Germany) and Belchite (Spain) are the attraction respondents are the least familiar with.

\subsection{Respondents' experiences and motives for visiting dark attractions}

Further questions examined the respondents' experience with dark tourism travel. Respondents were asked if they have ever participated in dark tourism. One-third of respondents 
have participated in this tourism form (32\%) while $68 \%$ of them have not experienced dark tourism before.

Respondents who participated in this form of tourism were asked to write the dark tourism site they have visited. Out of a total of 72 respondents who claim to have participated in dark tourism, 45 respondents indicated the exact dark tourism site they have visited.

The most frequent answers were Auschwitz Poland (16 respondents), Ovčar Memorial Home - Croatia (10 respondents), Anne Frank House in Amsterdam - Netherlands (6 respondents), Mirogoj Cemetery in Zagreb - Croatia (3 respondents), Jasenovac - Croatia concentration camp ( 2 respondents) and Westerbork - Netherlands camp (2 respondents). Other dark attractions visited are Holocaust Memorial - Berlin, Germany, city tour of sites related to medieval torture, witch burning, etc. - Edinburgh, Scotland, Flossenbürg - Flossenbürg concentration camp, Germany, Waterloo 1815 - Waterloo, Belgium, Dracula's Castle - Bran, Romania and the Stara Gradiška - Stara Gradiška concentration camp, Croatia (1 respondent). This question was combined with the question of visiting specific tourist attractions that are representatives of dark tourism, where it was found that 2/3 of respondents visited a dark tourism attraction without being aware of its connection with dark tourism.

Furthermore, the aim was to investigate the purpose of the visit to the dark tourism destination (Graph 3), and whether participation in dark tourism was the primary motive of the trip or whether an attraction was only an additional destination of another trip. Out of the 72 respondents who participated in dark tourism, $84.72 \%$ indicated that the visit to the dark attraction was an additional destination during another trip, while $\mathbf{1 5 . 2 8 \%}$ of respondents stated that participation in dark tourism was their primary destination.

The following questions were intended to explore respondents' interest in participating in dark tourism, as well as travel motives. Respondents were asked if they would like to participate in dark tourism, and if so, space was provided for writing desired destinations. Respondents who expressed a desire to participate in dark tourism represent $33.33 \%$ of respondents, those who do not want to participate in dark tourism represent $31.56 \%$, while $35.11 \%$ of respondents do not care whether they would participate in dark tourism.

To an open-ended question in which respondents could write which destinations they would like to visit, 61 of them wrote an answer. There are eight answers in which the tourist attractions that you want to visit are not specified, but the countries are written in response (Germany (3 respondents), Romania (2 respondents), Croatia (2 respondents), Spain (1 respondent), Bosnia and Herzegovina (1 respondent), the Netherlands (1 respondent), Iraq (1 respondent) and Ireland (1 respondent).

The largest number of respondents expressed a desire to visit Auschwitz (Poland), 27 of them. Furthermore, 3 respondents want to visit the Anne Frank House (Netherlands), four respondents want to visit the Paris Catacombs (France), Bran Castle (Romania) four respondents, Chernobyl) three respondents, Pompeii (Italy) one respondent, Dachau concentration camp (Germany) one respondent, Jasenovac (Croatia) one respondent, Srebrenica (Bosnia and Herzegovina) one respondent, National Memorial Museum September 11 - WTC (New York, USA) two respondents and battlefields one respondent. Nine respondents stated that they want to participate in dark tourism, but that they don't care about the location. 


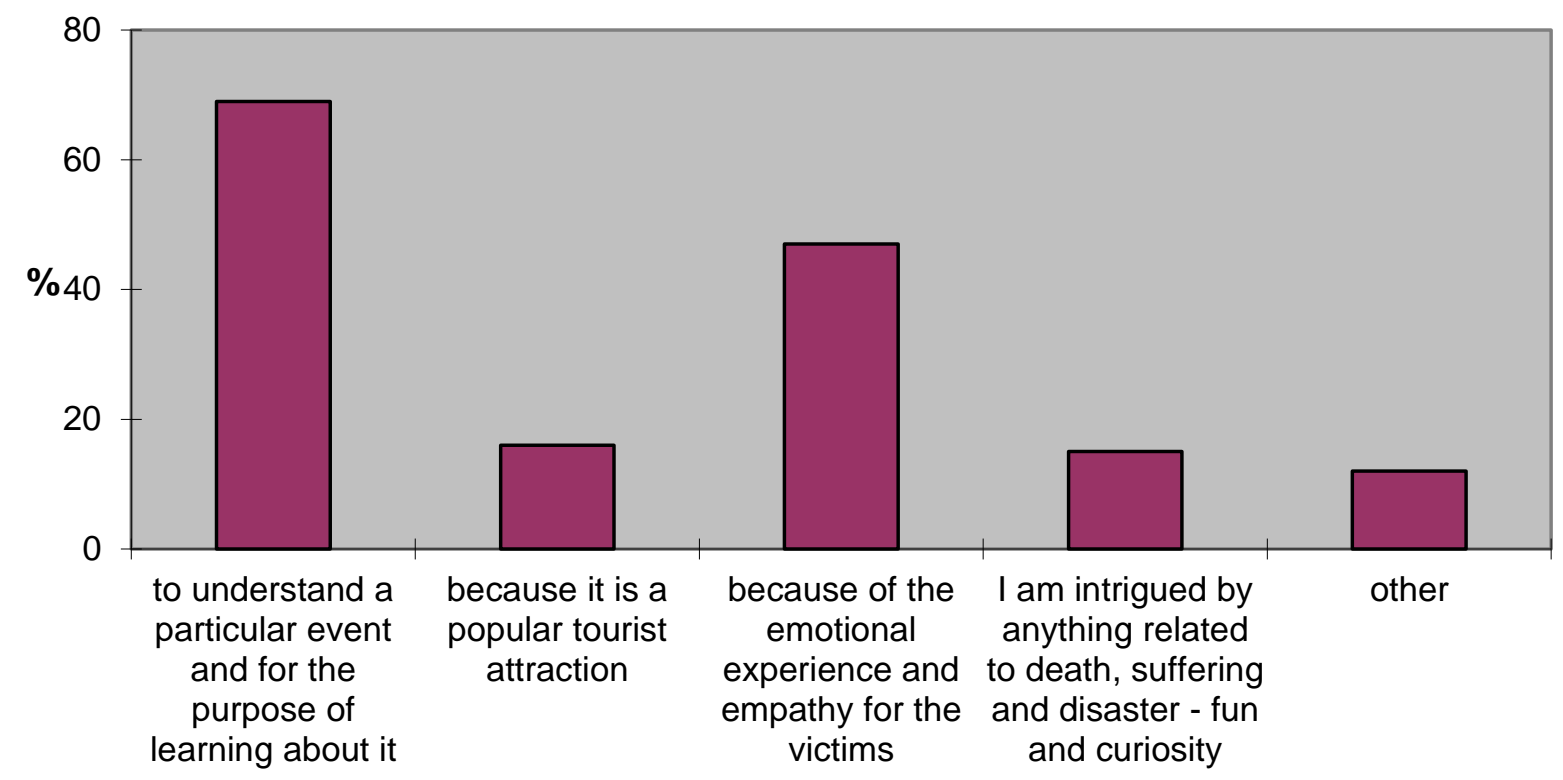

Graf. 3. Motives for the visit of dark tourism attractions (Juranović, 2017)

Respondents were given a choice of multiple answers to dark tourism motives (Chart 3). The largest number of respondents, 156 or $69.33 \%$, chose understanding and learning about an event as the motive for the visit. Furthermore, 105 or $46.67 \%$ of respondents chose emotional experience and empathy towards victims as the motive for the visit. The smallest number of respondents chose the popularity of the tourist attraction -37 or $16.44 \%$ of them, and the intrigue for death, suffering and catastrophes, i.e., fun and curiosity was chosen by 34 or $15.11 \%$ of respondents.

\subsection{Respondents' perception of the development of dark tourism}

The last group of questions concerned respondents' views on the potential of dark tourism in the Republic of Croatia, the development of dark tourism in the EU and the opinion of respondents on the decline/growth of demand for this form of tourism.

The following are the attitudes of the respondents about the possible development of certain types of dark tourism in Croatia. The majority of respondents, 169 or $75.11 \%$, believe that Croatia has the potential to develop dark tourism in places of war. The development of dark tourism in former prisons and courtrooms was chosen by $39.56 \%$ of respondents. Furthermore, the potential for the development of dark tourism in cemeteries was indicated by 61 respondents, i.e., $27.11 \%$, while 44 or $19.56 \%$ of respondents believe that Croatia has the potential to develop dark theme parks. The smallest number of respondents, 21 respondents, or $9.33 \%$ do not know which type of dark tourism has the potential for development in Croatia.

About the expected decline/growth of interest in tourist demand for dark tourism places, most respondents agreed that an increase in interest can be expected (70.67\%), while respondents who believe that interest in dark tourism will fall represent $29.33 \%$ of the entire sample. 


\section{Conclusion}

The increase in tourist trends, but also changes in the behavior of tourists and their interests have influenced the increase in demand for dark tourism. Motives for visiting dark attractions vary. While some seek entertainment and are motivated by an intrigue for death, others are interested in its educational character.

In the EU, one can find dark attractions that belong to the brightest spectrum, such as dark theme parks, all the way to those in the darkest category, such as mass murder sites. Thus, in the European Union, there are attractions associated with myths and legends such as haunted castles, cemeteries were celebrities or historical cemeteries rest, places of death of celebrities, former concentration camps, various museums, places of natural disasters, etc. The data on tourist trends available for individual attractions confirm the growth in demand for dark attractions. Attractions such as Pompeii, Auschwitz, the Colosseum in Rome, the Catacombs of Paris, etc., each year record an increase in the number of visitors and the prospects are such that this trend will continue in the future.

The research results are representative for the Croatian travel market. They indicate that a relatively small proportion of respondents have no idea what the term dark tourism means while most respondents are able to assume what dark tourism is and what dark attractions represent. Respondents' familiarity with the popular dark attractions in the EU is satisfactory. The vast majority of respondents are familiar with attractions that are globally recognizable dark attractions.

It is interesting to note that almost $2 / 3$ of the respondents did not consciously participate in dark tourism, which was determined by linking the question of participation in dark tourism and the question of whether they visited certain tourist attractions of dark tourism. This research question requires deeper reflection and analysis of the causality of this phenomenon, which is recommended to be determined in future research. Only then, it will be possible to give clearer implications for practice.

In past experiences with dark tourism, it was found that the respondents who participated in dark tourism mostly, over 90\% of them, visited attractions located in EU member states. Poland (Auschwitz) and Croatia (Ovčara Memorial Home) proved to be the two leading destinations visited by the respondents.

Opinions are divided regarding the interest in participating in dark tourism. About a third of the respondents want to participate in this form of tourism, one third did not express a desire to participate, while the last third of the respondents are indifferent. The destinations that have proven to be the most desirable are mostly those located within the European Union, with Auschwitz in Poland leading the way, as in the case of past experiences. This implies that marketers should work on the image of the attractions they represent to make them more recognizable and appealing to the general public.

Then, when it comes to the motives of visiting dark attractions, educational attractions are predominant (those attractions that allow visitors to better understand the event itself), as well as the emotional experience and sense of empathy for the victims. Motives that have proven to be rarer when choosing dark destinations are the popularity of the tourist attraction as well as the entertainment or curiosity of the visitors.

In conclusion, respondents believe that the Republic of Croatia has the most potential for the development of dark tourism in places affected by war destruction and in the facilities of former prisons and courtrooms. Furthermore, most respondents agreed that an increase in demand for the same could be expected. 
As far as the EU is concerned, this global region is competitive in the international tourism market and has the potential for further successful development, which was confirmed by analyzing available data on tourism trends, but also by a survey in which respondents showed interest in participating in dark tourism. Further development certainly requires more aggressive promotional activities, as well as a more detailed study of tourist demand and its motives. Research has shown that in the vast majority of cases, dark tourist attractions are not the main motive for taking a trip. Since the range of dark attractions is wide, it is necessary to observe each attraction individually and create such a product that will represent it adequately and which will ensure appropriate development while ensuring dignity, both for victims and all others potentially affected by these forms of tourism.

\section{Acknowledgements}

This research did not receive any specific grant from funding agencies in the public commercial, or not-for-profit sectors.

The authors declare no competing interests.

\section{References}

Daily Mail Online (2012.) 'Disaster tourism' boom for Giglio as day-trippers visit the Costa Concordia site. Retrieved May 20, 2018, from: http://www.dailymail.co.uk/travel/article-2188623/CostaConcordia-tragedy-Disaster-tourism-boom-Giglio-day-trippers-visit-stricken-ship.html.

Daily Mail Online (2014.) Cashing in on the Costa Concordia: Genoa locals turn cruise liner into a lucrative business with boat tours to stricken ship and offers of hotel rooms with a view. Retrieved May 20, 2018, from: http://www.dailymail.co.uk/travel/travel_news/article-2744697/CashingCosta-Concordia-Genoa-locals-turn-cruise-liner-lucrative-business-boat-tours-stricken-shipoffers-hotel-rooms-view.html.

Foley, M., \& Lennon, J. J. (1996). JFK and dark tourism: A fascination with assassination. International Journal of Heritage Studies, 2(4), 198-211. https://doi.org/10.1080/13527259608722175.

Fonseca, A.P., Seabra, C., \& Silva, C. (2016). Dark tourism: Concepts, typologies and sites. Journal of Tourism Research \& Hospitality. o(2). Retrieved February 6, 2018, from: https://www.scitechnol.com/download.php?download=peer-review-pdfs/dark-tourismconcepts-typologies-and-sites-Egqw.pdf.

Hooper, G., \& Lennon, J. J. (2017.) Dark tourism practice and interpretation. London and New York: Routledge.

Juranović, N. (2017) Mračni turizam i turizam katastrofe u EU [Dark tourism and tourism of catastrophe in EU]. Sveučilište J. Dobrile u Puli, Fakultet ekonomije i turizma dr. M. Mirković, Pula (Unpublished).

Kesar, O., \& Pavle, T. (2014). Obilježja i dosezi razvoja memorijalnog turizma u Hrvatskoj [Characteristics and achievements of the development of memorial tourism in Croatia]. Liburna, 3(1), 49-88. Retrieved 16 March 2018, from: https://hrcak.srce.hr/file/213735.

Lennon, J., \& Foley, M. (2007). Dark tourism: The attraction of death and disaster. London: Thomson Learning. 
MMNieuws (2016.) From Dark Ages to dark tourism - Death, spirituality and the modern tourist. Retrieved 7 May 2018, from: http://www.mmnieuws.nl/article/from-dark-ages-to-darktourism-death-spirituality-and-the-modern-tourist/.

Robinson, N. (2015). Dark tourism motivations: An investigation into the motivations of visitors to sites associated with dark tourism. Doctoral Thesis, Univerity of Salford. Retrieved 7 March 2018, from: http://usir.salford.ac.uk/36776/5/dark\%20tourism.pdf.

Seaton A.V., \& Lennon, J. (2004). Moral panics, ulterior motives and alterior desires: Thanatourism in the early 21st century. In T. V. Singh (Ed.), New horizons in tourism: Strange experiences and stranger practices (pp. 63-82). Wallingford: CABI.

Sharpley, R., \& Stone, P. R. (2009). The darker side of travel the theory and practice of dark tourism. Bristol: Channel View Publications.

Stone, P. (2005). Cosuming Dark Tourism: a call for research. e-Review of Tourism Research (eRTR). 3(5), 109.-117. Retrieved 6 March 2018, from: https://works.bepress.com/philip_stone/5/download/.

Stone, P. (2010). Death, Dying and Dark Tourism in Contemporary Society: A Theoretical and Empirical Analysis. Doctoral Thesis, University of Central Lancashire. Retrieved 9 February 2018, from: http://clok.uclan.ac.uk/1870/1/StonePPhD thesis final.pdf.

Strielkowski, W. (2013). Mystery and thriller tourism: Novel solutions for European cities. Turizam: međunarodni znanstveno-stručni časopis, 61(3), 277-287. Retrieved 9 March 2018, from: https://hrcak.srce.hr/file/163425.

Tarlow, P. (2005): Drk tourism: the appealing “dark" side of tourism and more in: (ed. Novelli, M.) Niche Tourism, Taylor and Francis group, DOI: 10.1016/B978-0-7506-6133-1.50012-3. p. 47-58.

The Conversation (2016). It may be macabre, but dark tourism helps us learn from the worst of human history. Retrieved 7 May 2018, from: http://theconversation.com/it-may-be-macabre-butdark-tourism-helps-us-learn-from-the-worst-of-human-history-60966.

The Telegraph (2014). Tourists offered boat tours to see the Costa Concordia cruise liner. Retrieved 20 May 2018, from:

https://www.telegraph.co.uk/news/worldnews/europe/italy/11075446/Tourists-offeredboat-tours-to-see-the-Costa-Concordia-cruise-liner.html.

UNWTO (2019). International tourism highlights. Retrieved 2 November 2020, from: https://www.eunwto.org/doi/pdf/10.18111/9789284421152.

Vukonić, B. (2010). Turizam: budućnost mnogih iluzija [Tourism: The future of many illusions]. Zagreb: Plejada. 
N. Juranović, I. Slivar \& S. Kovačić - Dark Tourism in the EU: Are We Aware of Taking Part in It?

C O A s 